\title{
レーザー溶接における蒸発粒子の挙動とプラズマ パラメータ測定
}

金 鍾道 $* \cdot$ 片山 聖二 **・竹本 正 $* * \cdot$ 松縄 朗 $* *$

（1996 年 3 月 25 日 受理）

\section{Observation of Evaporated Particles Behaviors and Plasma Parameters in Laser Welding}

\author{
Jong-Do KIM*, Seiji KATAYAMA**, Tadashi TAKEMOTO** and Akira MATSUNAWA**
}

(Received March 25, 1996)

\begin{abstract}
This study was undertaken to obtain a fundamental knowledge of pulsed laser welding phenomena, especially evaporation mechanism of different aluminum alloys. The dynamic behavior of $\mathrm{Al}-\mathrm{Mg}$ alloys plume was very unstable and its fluctuation period was about 450 to 500 $\mu \mathrm{s}$. This instability was closely related to the unstable motion of a keyhole during laser irradiation. It was confirmed that the resonant lines of $\mathrm{Al}$ and $\mathrm{Mg}$ were strongly self-absorbed, in particular in the vicinity of pool surface. The intensities of molecular spectra of $\mathrm{AlO}$ and $\mathrm{MgO}$ were different each other depending on the power density of a laser beam. Under the low power density condition, the $\mathrm{MgO}$ band spectrum was predominant in intensity, while the $\mathrm{AlO}$ spectra became much stronger with an increase in the power density. These behaviors have been attributed to the difference in evaporation phenomena of $\mathrm{Al}$ and $\mathrm{Mg}$ metals with different boiling points and latent heats of vaporization. The time-averaged plume temperature and electron number density at $1 \mathrm{~mm}$ above the surface were determined by spectroscopic methods, and consequently the obtained temperature was $3,280 \pm 150 \mathrm{~K}$ and the electron number density was $1.85 \times 10^{19} 1 / \mathrm{m}^{3}$.
\end{abstract}

Key Words: Evaporation phenomena, Volatile element, High speed photography, Plume temperature, Electron number density

\footnotetext{
*大阪大学大学院工学部生産加工工学専攻（干 567 茨木市美穂ヶ丘 11-1）

**大阪大学接合科学研究所 ( 7567 茨木市美穂ヶ丘 11-1)

* Department of Welding and Production Engineering, Faculty of Engineering, Osaka University (11-1 Mihogaoka, Ibaraki, Osaka 567)

* * Joining and Welding Research Institute, Osaka University (11-1 Mihogaoka, Ibaraki, Osaka 567)
} 


\section{1. 緒言}

前報1)では, $\mathrm{Al}-\mathrm{Mg}$ 合金のパルス $\mathrm{Nd}^{3+}: \mathrm{YAG}$ レーザー溶接時に誘起されるプルームの発光分 光分析を行い，種々のガス雾囲気中に招いて励 起される合金元素の蒸発種と化学反応種の同定 ならびにそれらの発光特性を明らかにした。す なわち，アルミニウム合金の主な合金元素であ る $\mathrm{Al}$ と $\mathrm{Mg}$ をはじめ, $\mathrm{Mn}, \mathrm{Cr}$ な゙の多数の中性 原子と化学反応種が検出され，その発光特性は アーク励起によるスペクトル強度の值とよく一 致していることを示した。また， $\mathrm{Al}$ とg原子の 激しい自己吸収現象が生じることや $\mathrm{Mg}$ の一価イ オン線が同定されることより，多量の $\mathrm{Al}$ および $\mathrm{Mg}$ 原子が蒸発しており, 誘起プルームは弱電離 プラズマであることが判明した。さらに，プルー ムの物理量計測には, $\mathrm{Cr}$ と $\mathrm{Mg}$ の中性原子線, $\mathrm{Mg}$ の一価イオン線などが有効であることを示唆し た。

本報では，前報で得られた結果に基づいて， $\mathrm{Al}-\mathrm{Mg}$ 系合金 A5083 のレーザー溶接時に生じる 合金元素の蒸発挙動を調べるため, 誘起プルー ムの超高速撮影による挙動解析と発光分光分析 法により，スペクトル線強度の空間分布および 時間変化について詳細な検討を行った。さらに 発光スペクトルの相対強度測定法により，プラ ズマの基本的物理量である温度および電子密度 の推定を試みた。

\section{2. 供試材料，実験装置および実験方法}

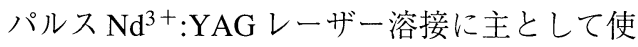

用した材料は，約 $4.6 \mathrm{mass} \% \mathrm{Mg}$ を含有する $\mathrm{Al}-\mathrm{Mg}$ 系合金 A5083 である。Table I に主な合金元素で ある $\mathrm{Al}$ および $\mathrm{Mg}$ の物理定数2,3)を示す。 $\mathrm{Mg}$ の 蒸発温度と蒸発時の潜熱は $\mathrm{Al}$ より非常に低いこ とがわかる。

レーザー誘起プラズマの時間変化の挙動の観 察には，ストリークカメラ(最大ストリーク速 度 : $300 \mathrm{~m} / \mathrm{s})$ と高速ビデオカメラ $($ 最大撮影速度： 40,500f/s)を同期させ，プルームのストリーク像 とフレーム像を対応させながら $1.16 \mu \mathrm{s}$ の時間分 解能でプルームの挙動を解析した。超高速撮影 システムの模式図を Fig. 1 に示す。

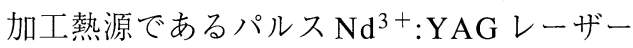
$(\lambda=1.064 \mu \mathrm{m})$ 装置と溶接方法, 誘起プルームの 発光分光分析に用いた光学系は前報1） と同様で ある。発光分光時の主なレーザー照射条件は，大 気中に扔いてパルスエネルギー $\left(E_{0}\right) 80 \mathrm{~J} / \mathrm{p}$ ，パルス 時間 $\left(\tau_{\mathrm{p}}\right) 21 \mathrm{~ms}$ の矩形波でパワー密度は $1.0 \times$ $10^{10} \mathrm{~W} / \mathrm{m}^{2}$ である。光電測光によるレーザー誘起 プルームの発光スペクトルの相対強度測定では,

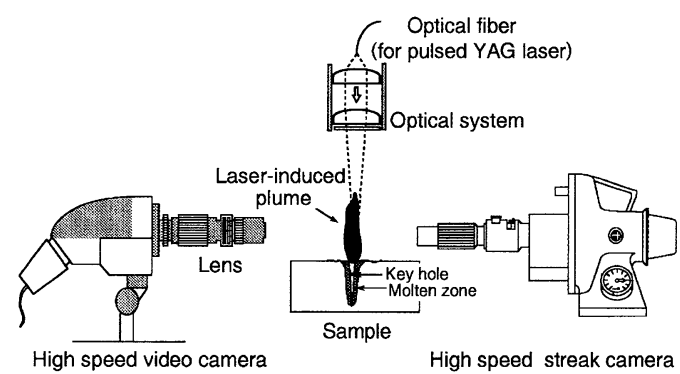

Fig. 1 Schematic of experimental set-up for observation of plume induced by pulsed Nd:YAG laser irradiation.

Table I Physical constants of pure aluminium and pure magnesium.

\begin{tabular}{ccccccccc}
\hline \hline & & & Melting & Boiling \\
Atomic Atomic & $\begin{array}{c}\text { Ionization } \\
\text { Point } \\
{[\mathrm{K}]}\end{array}$ & $\begin{array}{c}\text { Point } \\
{[\mathrm{K}]}\end{array}$ & $\begin{array}{c}\text { Potential of } \\
{[\mathrm{eV}]}\end{array}$ & $\begin{array}{c}\text { Fusion } \\
{\left[10^{3} \mathrm{~J} / \mathrm{mole}\right]}\end{array}$ & $\begin{array}{c}\text { Heat of } \\
\text { Vaporization }\end{array}$ & $\begin{array}{c}\text { Thermal } \\
\text { Conductivity } \\
\text { (at } 293 \mathrm{~K} / \mathrm{mole}] \\
{[\mathrm{W} / \mathrm{m} \cdot \mathrm{K}]}\end{array}$ \\
\hline $\begin{array}{c}\text { Pure } \\
\mathrm{Al}\end{array}$ & 13 & 26.9815 & 933.26 & $2750 \pm 50$ & 5.984 & $8.40 \pm 0.16$ & 293.8 & 238 \\
$\begin{array}{c}\text { Pure } \\
\mathrm{Mg}\end{array}$ & 12 & 24.305 & $\begin{array}{c}932 \pm \\
0.5\end{array}$ & $1376 \pm 5$ & 7.644 & $8.96 \pm 0.2$ & 128.7 & 167 \\
\hline \hline
\end{tabular}


それぞれのスペクトルの時間的強度変化をアナ ライザーにより $100 \mathrm{kHz}$ のデー夕処理速度で 10 回 採取し，そのデータを A/D 変換した後，コン ピュータによって時間平均化処理を行った。得 られたスペクトル強度に対しては標準光源によ る感度補正を行った。

\section{3. 実験結果および考察}

\section{1 レーザー誘起プルームの挙動}

レーザー溶接中に誘起されるプルームの挙動 を，超高速撮影したプルームの観察結果と単一 波長の発光スペクトル強度の時間変化の計測結 果に基づいて解析を行った。その結果をFig. 2 お よびFig. 3に示す。なお, 発光強度の時間変化の 観察には，アルミニウム合金A5083に微量含有 されている $\mathrm{Cr}$ の中性原子線 $(\lambda=425.435 \mathrm{~nm}$, $0.116 \mathrm{mass} \%)$ を用いた。中性原子として, 含有量 が多い合金元素からのAlIあるいはMgIを選ばな かったのは，これらは自己吸収の影響が大きく， 正確な強度測定には不適当であるためである。 そこで，自己吸収が生じない CrI を選択した。

Fig. 2は誘起プルームの挙動をストリーク像と フレーム像を対応させて解析し, その変動状況 を可視化したものである。撮影条件は，ストリー ク速度 $\left(V_{\mathrm{s}}\right)=86.12 \mathrm{~m} / \mathrm{s}$ ，スリット幅 $(W)=0.1 \mathrm{~mm}$, 時間分解能 $\left(R_{\mathrm{t}}\right)=1.16 \mu \mathrm{s}$ であり，パルス波形は レーザー照射時間 $\left(\tau_{\mathrm{p}}\right)=7 \mathrm{~ms}$ の矩形波である。
$\mathrm{A} 5083$ の誘起プルームは約 $450 \sim 500 \mu \mathrm{s}$ の周期で 激しく変動していることが明らかとなった。ま た，プルームの膨張挙動をストリーク像より計 測した結果, プルームは最大 $270 \mathrm{~m} / \mathrm{s}$ の亜音速で 上方へ伝播していることがわかった。

プルームのこのような挙動はFig. 3の発光スペ クトル強度の計測結果からも認められた。Fig. 3

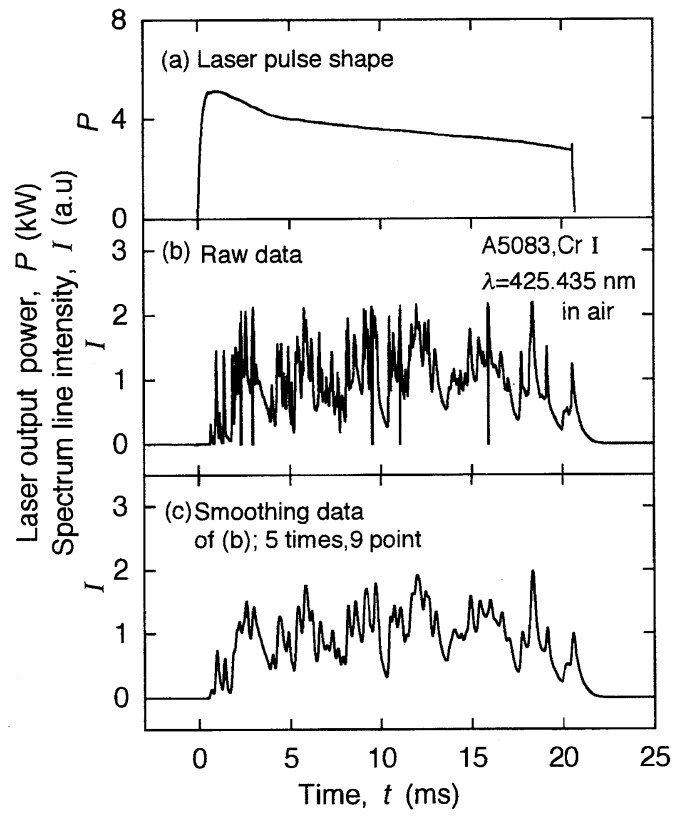

Fig. 3 Variation in spectral intensity as a function of time $\left(E_{0}=80 \mathrm{~J} / \mathrm{p}, \tau_{\mathrm{p}}=21 \mathrm{~ms}\right)$.

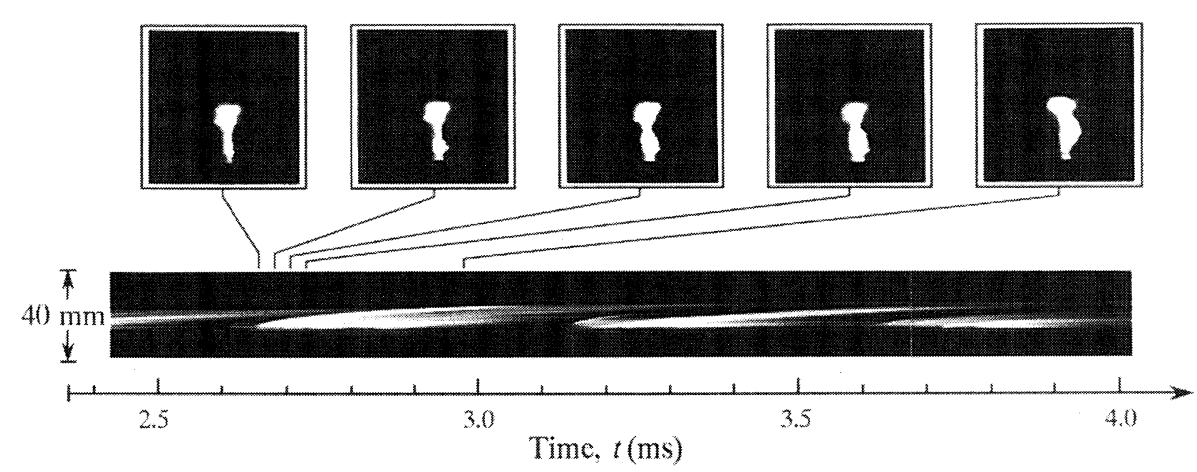

Fig. 2 High speed streak image (lower part) and frame photographs (upper part) of plume induced from A5083 with pulsed laser in air $\left(V_{\mathrm{s}}=86.12 \mathrm{~m} / \mathrm{s}, R t=1.16 \mu \mathrm{s}, n_{\mathrm{f}}=40,500 \mathrm{f} / \mathrm{s}, \tau_{\mathrm{p}}=7 \mathrm{~ms}, E_{0}=28.7 \mathrm{~J} / \mathrm{p}\right)$. 
(a),(b)および(c)は，それぞれ計測時に用いたレー ザー出力の強度, 発光スペクトル線強度の生 データおよびその生デー夕を5次の9点平滑化処 理をしたものを示す。レーザー照射中における 誘起プルームの発光強度は, 特定時間でのピー クが存在せず，短時間に激しく変動しているこ とがわかる。

以上の結果から，A5083 合金における誘起プ ルームはレーザー照射中約 $450 \sim 500 \mu \mathrm{s}$ の周期性 を持って激しく変動しており，溶接時の合金元 素の蒸発挙動も同様に変動していると考えられ る。このようなプルーム変動は，レーザービーム と材料とのエネルギーカップリングの変化によ るキーホールの周期的変動に起因するものと推 察される4)。

\section{2 発光スペクトル線強度の時間変化および 空間分布}

A5083 のパルスレーザー溶接時に誘起される 励起種の発光強度の時間变化について計測を 行った。さらに, 試料表面から高さ方向への発光 強度の変化と化学反応の挙動を観察し，合金元 素の蒸発挙動を検討した。

まず，レーザー照射時の種々の発光スペクト ル強度の時間变化に伴う挙動を Fig. 4 と Fig. 5 に 示す。同時計測を行った波長域は 496〜 524nm で，それぞれの発光スペクトル強度のデー夕は， $20 \mathrm{~ms}$ のレーザー照射時間 $\left(\tau_{\mathrm{p}}\right)$ 中 $0 \sim 20.2 \mathrm{~ms}$ の範

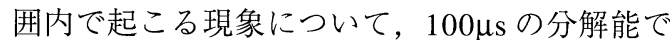
ゲートをずらしながらそれぞれ10回のデー夕を 検出器に取り込んで積算したものである。Fig. 4 にはレーザー照射終了直前のごく短い時間のな かで生じる発光スペクトルの強度の変化を示す。 一方，Fig. 5はレーザー照射時間の全般にわたっ て $\mathrm{AlO}(507.94 \mathrm{~nm})$ と $\mathrm{MgO}(500.73 \mathrm{~nm})$ の挙動を計測 し，それぞれの相対強度比を求めた結果を示す。 これらの結果から，レーザー照射中，レーザーの パワー密度が高い時には $\mathrm{AlO}$ の発光強度が $\mathrm{MgO}$ よりはるかに大きいが，レーザー照射開始直後 と終了直前においてパワー密度が低いときには, それらの強度分布が逆転し, $\mathrm{MgO}$ の強度がむし ろ $\mathrm{AlO}$ より高くなることがわかる。このような 現象が起こる理由は，TableIに示したように, $\mathrm{Mg}$

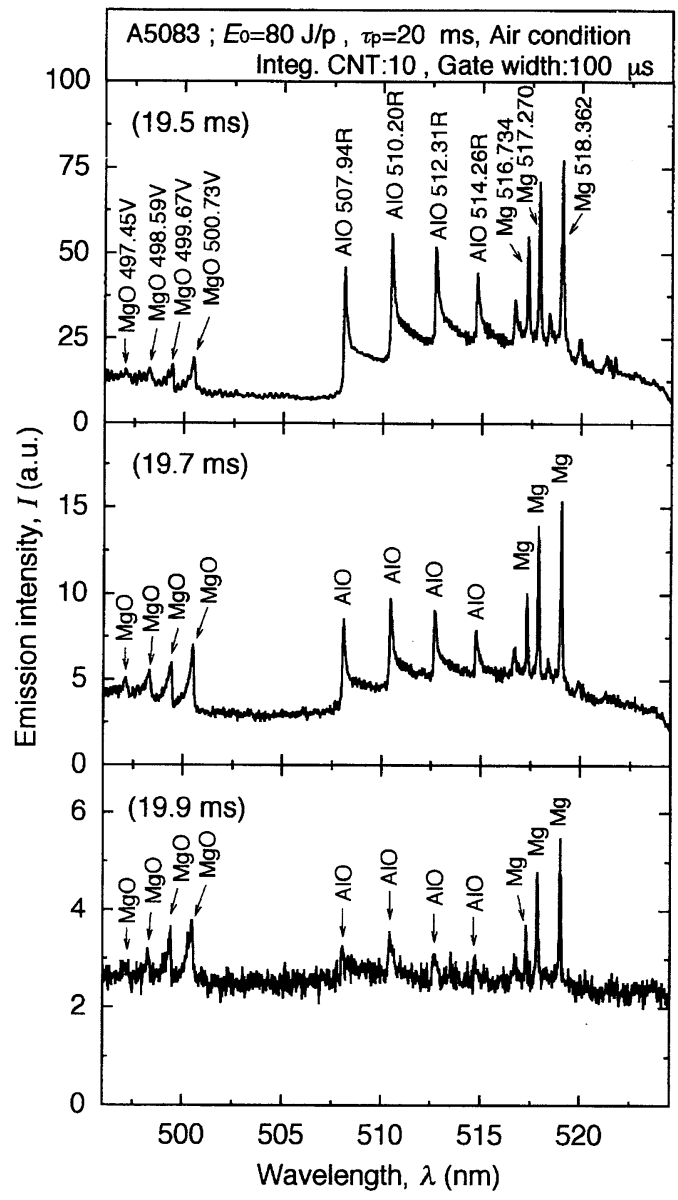

Fig. 4 Evolution of relative intensities of emission lines as a function of time.

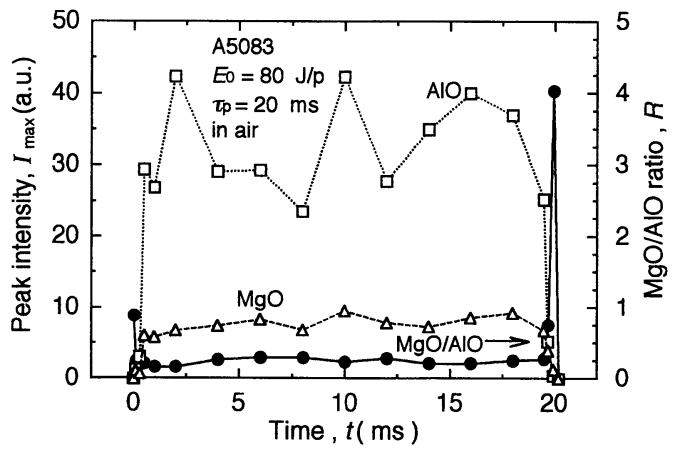

Fig. 5 Variation in relative intensities of $\mathrm{MgO}$ and $\mathrm{AlO}$ molecular spectra as a function of time.

の沸点および蒸発潜熱 $\left(1376 \pm 5 \mathrm{~K}, 128.7 \times 10^{3} \mathrm{~J} /\right.$ $\mathrm{mol})$ が $\mathrm{Al}\left(2750 \pm 50 \mathrm{~K}, 293.8 \times 10^{3} \mathrm{~J} / \mathrm{mol}\right)$ より半 


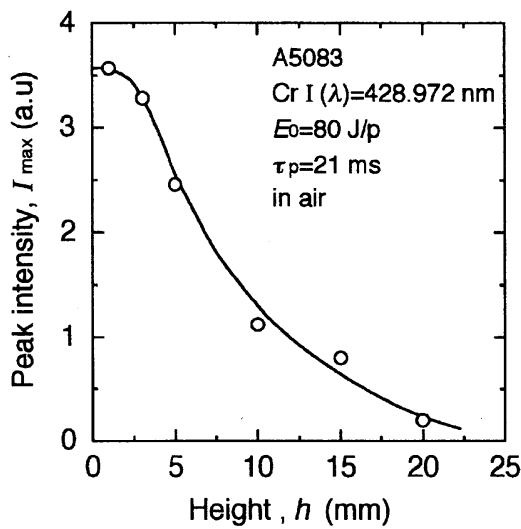

(a)

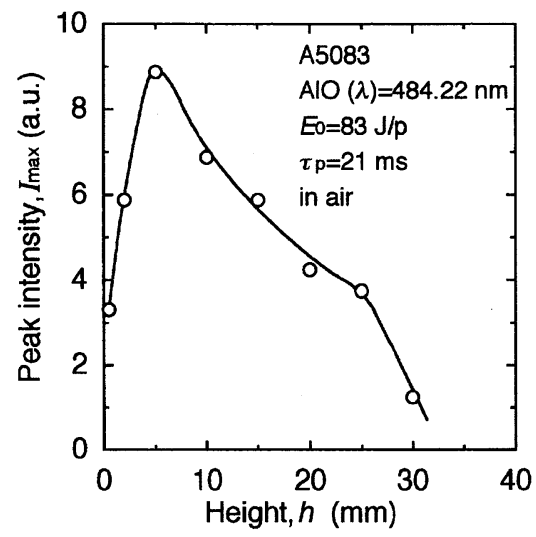

(b)

Fig. 6 Spatial distribution of spectral peak intensity as a function of height from specimens surface.

分程度低いことと溶融池の温度差に起因すると 考えられる。すなわち，レーザー照射開始直後と 終了直前では, 溶融池表面の温度が低く, $\mathrm{Al}$ の 十分な蒸発温度まで到達していないため, 沸点 および蒸発潜熱が低い $\mathrm{Mg}$ の蒸発が優先的に起こ り，その結果， $\mathrm{MgO} へ の$ 化学反応による発光も $\mathrm{AlO}$ より強くなったものと推察される。

次に, 光電測定法と写真測光法を用いて, 種々 の励起種の空間分布について計測を行った。

Fig. 6に中性原子およびAlOの分子スペクトル のプルーム成長方向への強度変化を光電測光に よって測定した結果を示す。計測には，中性原子 スペクトルとして $\operatorname{CrI}(\lambda=428.972 \mathrm{~nm})$ を用い, 分 子スペクトルとしては $\mathrm{AlO}(484.22 \mathrm{~nm})$ を用いた。 これらの中性原子線および分子線は，それぞれ 永存線および永存バンドヘッド5) としてその強 度が強く，他の波長より十分に離れているので 干渉の影響を受けていないことから選択した。 レーザー照射条件は， $\tau_{\mathrm{p}}=21 \mathrm{~ms}, E_{0}=80 \mathrm{~J} / \mathrm{P}$ で あり，試料表面はレーザービームの焦点にある。 Fig. 6(a)㧍よび(b)から，中性原子スペクトルの強 度は試料表面付近で最大となり，表面より離れ るほど弱くなることがわかる。一方， $\mathrm{AlO}$ の分子 スペクトルの場合, その強度は試料表面付近で 弱く，上方に行くほど高くなり，高さ約 $5 \mathrm{~mm} の$ 位置で最大となり，その後緩やかに減少してい る。これはパルスレーザー照射によって溶融部 から蒸発される $\mathrm{Al}$ 原子が，試料表面上の空間を 移動中に大気中の酸素と化学反応を起こしてい
ることを示す。すなわち，AlO分子スペクトルは， 蒸発した金属原子と大気中の酸素との化学反応 によって形成され，放射したものであると判断 される。

また，Fig. 7にAlI(394.401 と396.152nm)および $\operatorname{MgI}(285.213 \mathrm{~nm})$ の自己吸収現象の空間挙動につ

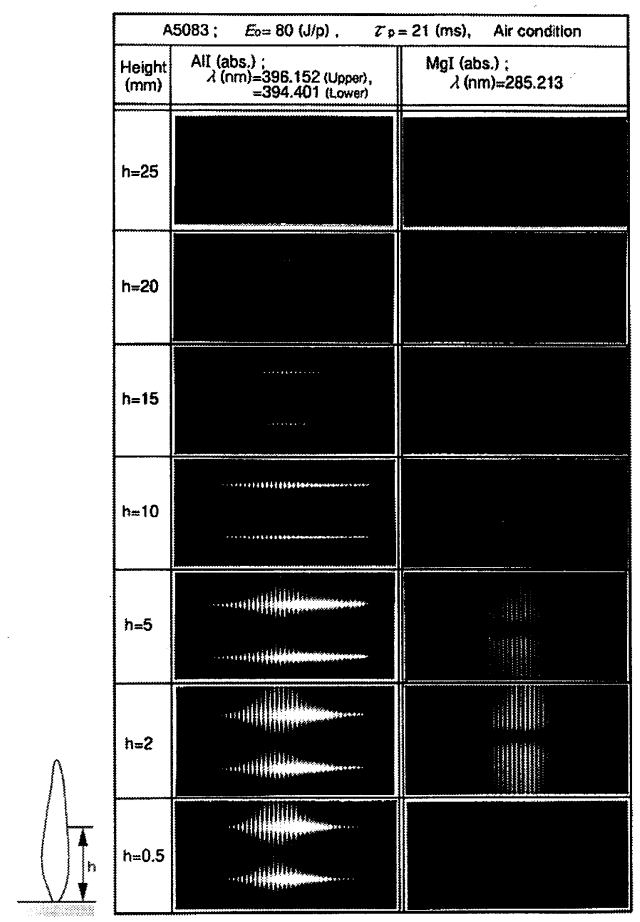

Fig. 7 Spatial distribution of atomic spectra intensity with self-absorption as a function of height from specimen surface. 
いて，写真測光により可視化を試みた結果を示 す。写真全体で見える縦方向の数多い細い線は 分光測光時に用いた光学系の 40 本のファイバで 構成されているバンドルファイバのそれぞれの 情報であり，これは誘起プルームの横方向の空 間分布を示す。写真からわかるように，いずれも 激しい自己吸収が起こっており，その程度は $\mathrm{Mg}$ の方がさらに著しい。なお，自己吸収現象は試料 表面に近いほど強く生じ, プルーム上方ほど弱 くなっている。すなわち，試料表面から離れるほ ど，中央部の黒い線の幅が狭くなり，吸収線が普 通の中性原子線に変わっていくことから，レー ザー溶接時には多量の $\mathrm{Al}$ と $\mathrm{Mg}$ 原子が溶融池表 面から蒸発し，上方ほどそれらの原子状態の濃 度は少なくなることがわかる。

\section{3 発光スペクトル線強度に及ぼすパワー密} 度の影響

$\mathrm{Al}-\mathrm{Mg}$ 合金のパルスレーザー溶接時に生じる 合金元素の蒸発挙動とその発光強度に及ぼすパ ワー密度(レーザーパルスエネルギー)の影響を調 ベるために，励起種の発光スペクトルの強度変 化をマルチチャンネル分光測光システムを用い て計測した。分析に用いた波長域は $\mathrm{AlO}$ と $\mathrm{MgO}$ の発光強度変化の同時計測が可能な $496 \sim 524$ $\mathrm{nm}$ であり, 主な合金元素の $\mathrm{Al}$ と $\mathrm{Mg}$ の蒸発挙動 の予測が可能であることから選んだものである。 レーザー照射条件は，A5083試料表面がレーザー の焦点位置にあり，パルス幅 $\left(\tau_{\mathrm{p}}\right)$ は $20 \mathrm{~ms}$ で，パ ルスエネルギーとして $26 \mathrm{~J} / \mathrm{p}$ から $76 \mathrm{~J} / \mathrm{p}$ まで 17 等 分に分け大気中でレーザーを照射し，パワー密 度による発光スペクトルの強度変化を観察した。 誘起プルームの観察位置は試料表面より $3 \mathrm{~mm}$ の 高さであり，レーザー照射後 $2 \mathrm{~ms}$ 後の現象を約 $100 \mu \mathrm{s}$ 間検出器に取り込んで 10 回のデー夕を積 算した。その結果を Fig. 8 抢よび Fig. 9 に示す。 Fig. 8はレーザーのパワー密度の変化によって発 光強度の変化が著しいところをゲイン值を上げ て現したものである。パワー密度が高くなると， $\mathrm{MgO}$ と $\mathrm{AlO}$ の発光強度が逆転することが認めら れる。したがって，このような発光挙動をみせて いる $\mathrm{MgO}$ および $\mathrm{AlO}$ に注目し， $\mathrm{MgO}(500.73 \mathrm{~nm})$ と $\mathrm{AlO}(507.94 \mathrm{~nm})$ の相対強度比をレーザーパワー

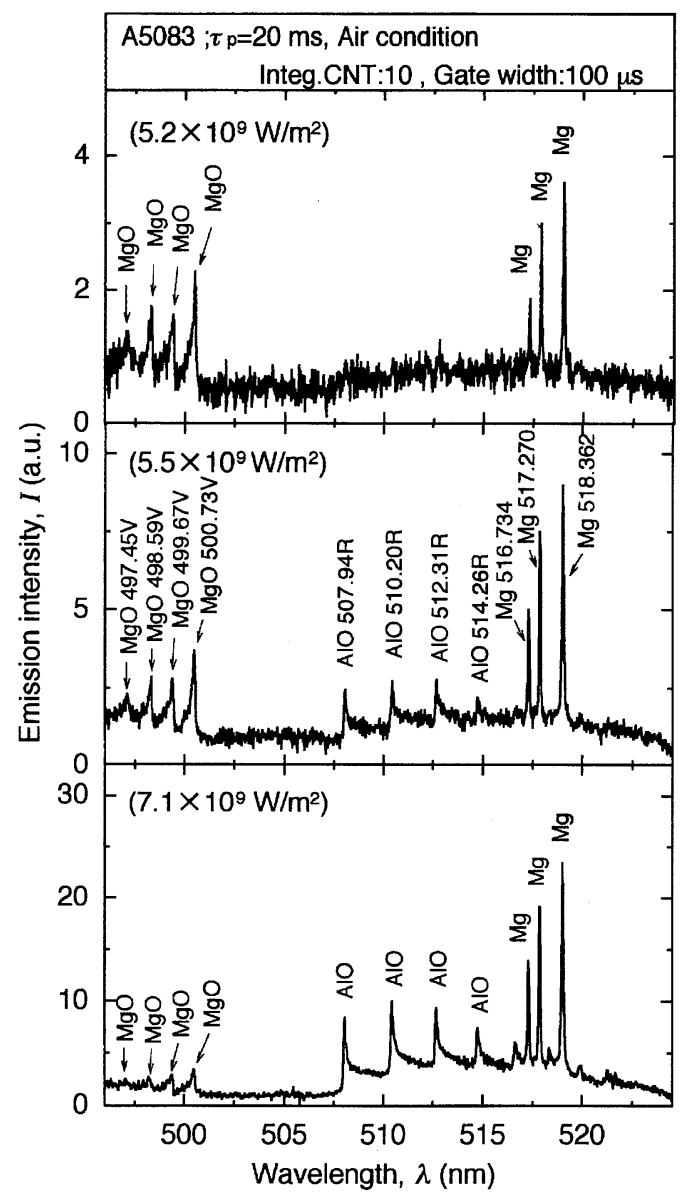

Fig. 8 Evolution of relative intensities of emission lines as a function of laser power density.

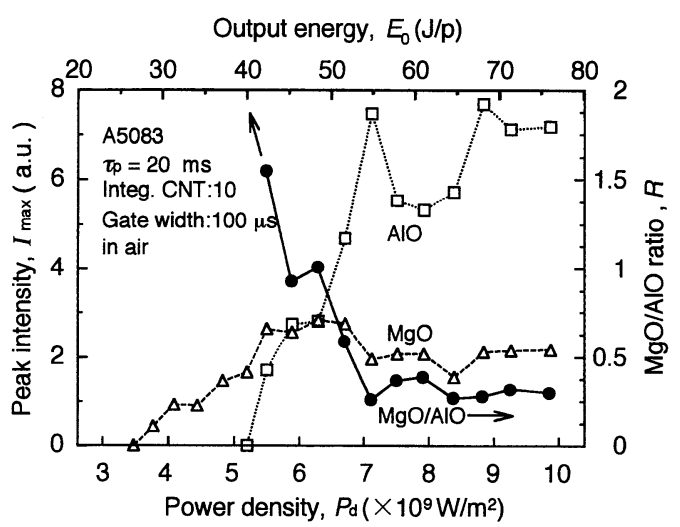

Fig. 9 Variation in relative intensities of $\mathrm{MgO}$ and $\mathrm{AlO}$ molecular spectra as a function of laser power density. 
密度(パルスエネルギー)に対してまとめたものが Fig. 9 である。これらの結果からわかるように， 低パワー密度のレーザーを照射した時には，A1O は検出されず， $\mathrm{MgO}$ だけが同定されている。パ ワー密度が増加していくと $\mathrm{AlO}$ の発光も始まり, より高パワー密度では $\mathrm{MgO}$ と $\mathrm{AlO} の$ 強度は逆転 し， $\mathrm{AlO}$ の発光が支配的になる。また， $\mathrm{MgO} の$ 発光強度は, レーザーのパワー密度の増加に 従って $\mathrm{AlO} と と も に$ 解離されるまでは大きくな るはずであるが，パワー密度が約 $6 \times 10^{9} \mathrm{~W} / \mathrm{m}^{2}$ 以 上では発光強度の上昇が生じていない。

このような現象が生じる原因は，前節での励 起種の発光スペクトル強度の時間変化の原因と まったく同様に考えられる。すなわち，低パワー 密度のレーザー照射条件においては，溶融池の 表面温度が低く $\mathrm{Mg}$ の蒸発が主に起こり， $\mathrm{MgO}$ へ の化学反応による発光が顕著になる。さらにパ ワー密度を増加していくと, 溶融池の表面温度 も上昇して $\mathrm{Al}$ も多量に蒸発され, 化学反応によ る $\mathrm{AlO}$ の発光が $\mathrm{MgO}$ よりるかに強くなると考 えられる。一方, 高パワー密度で $\mathrm{MgO}$ の発光強 度が強くならないのは，本分析に用いたA5083の $\mathrm{Mg}$ 含有量が4.6mass\%にすぎないためである。

\section{4 プルーム温度および電子密度の測定}

分光学的手法によるプラズマの診断法は, 物 理現象を解明する場合に有効な方法の一つであ る。しかし，プラズマからの放射強度の絶対量を 測定することは技術的に簡単ではない。そこで, 物性は，一般に，ある粒子の2種類あるいはそれ 以上のスペクトル線の放射強度の相対量を測定 することにより求められる 6-10)。

本計測法では, プルームが局所熱平衡(LTE)で あると仮定すると，式(1)が成立する。このこと から，複数のスペクトルの強度を測定し，それら の相対強度の関係よりプルームの温度を求めた。

$$
\begin{aligned}
& \operatorname{In}\left(\frac{I_{\mathrm{nm}} \lambda_{\mathrm{nm}}}{g_{\mathrm{n}} A_{\mathrm{nm}}}\right)=-\frac{E_{\mathrm{n}}}{k T}+\operatorname{In}\left(\frac{N_{0} h c}{Z}\right) \\
& \text { ここで} \\
& I_{\mathrm{nm}}: \text { プラズマのスペクトル線の強度 }(\mathrm{n} \rightarrow \mathrm{m}) \\
& \lambda_{\mathrm{nm}}: \text { スペクトル線の波長 }(\mathrm{n} \rightarrow \mathrm{m}) \\
& g_{\mathrm{n}} \quad: \mathrm{n} \text { 番目にお施る統計的重み }
\end{aligned}
$$

$E_{\mathrm{n}}: \mathrm{n}$ 番目の励起エネルギーレベル

$k$ : ボルツマン定数

$N_{0}$ : プラズマ単位体積当りの全原子数

$h$ : プランク定数

$\mathrm{Z}$ : 温度 $\mathrm{T}$ に扮けるその原子の分配関数

c : 光の速度

この関係から, 多数のスペクトル線について 縦軸に $\ln \left(I_{\mathrm{nm}} \lambda_{\mathrm{nm}} / g_{\mathrm{n}} A_{\mathrm{nm}}\right)$, 横軸に $E_{\mathrm{n}}$ をとり，プ ロットすると, 勾配は- $1 /(k T)$ の直線で表され, 温 度が求まる。実際は, 測定誤差や遷移確率 $A_{\mathrm{nm}}$ の 不正確さなどの要因のため, 測定結果は直線の まわりにバラつく。このため, 最小二乗法などの 手段で傾きを求め, その傾きから温度 $T$ を求め る。

Table II A5083のレーザー誘起プルームの温 度計測に用いた線スペクトルとボルツマンプ ロットを行うときのそれぞれのラインに対する 統計的重みや遷移確率11,12)を示す。計測に用い たCrI線は，A5083に0.12mass\%含有されている $\mathrm{Cr}$ 元素からのもので, 自己吸収が生じず, 他の スペクトル線の干渉を受けにくいため選定した。

Fig. 10 に計測結果から求めたボルツマンプ ロットを示す。レーザー照射条件としては， $E_{0}=$ $80 \mathrm{~J} / \mathrm{p}, \tau_{\mathrm{p}}=21 \mathrm{~ms}$ で，パワー密度は $1.0 \times 10^{10}$ $\mathrm{W} / \mathrm{m}^{2}$ である。発光スペクトルの相対強度は, 試 料表面より高さ $1 \mathrm{~mm}$ の位置でそれぞれのスぺク トルの時間的変化を $100 \mathrm{kHz}$ のデー夕処理速度で 10 回採取し，そのデー夕を $\mathrm{A} / \mathrm{D}$ 変換した後，コ ンピュータによって時間平均化した。得られた スペクトル強度については標準光源による感度 補正を行った。その結果，プルームの温度は3280

Table II Physical property of CrI spectral lines.

\begin{tabular}{ccc}
\hline \hline$\lambda(\mathrm{nm})$ & $E_{\mathrm{n}}(\mathrm{eV})$ & $g \cdot A\left(10^{8} / \mathrm{s}\right)$ \\
\hline 357.869 & 3.46 & 8.3 \\
359.349 & 3.45 & 7.0 \\
360.553 & 3.44 & 5.2 \\
425.435 & 2.91 & 2.0 \\
427.480 & 2.90 & 1.5 \\
428.972 & 2.90 & 0.95 \\
\hline \hline
\end{tabular}




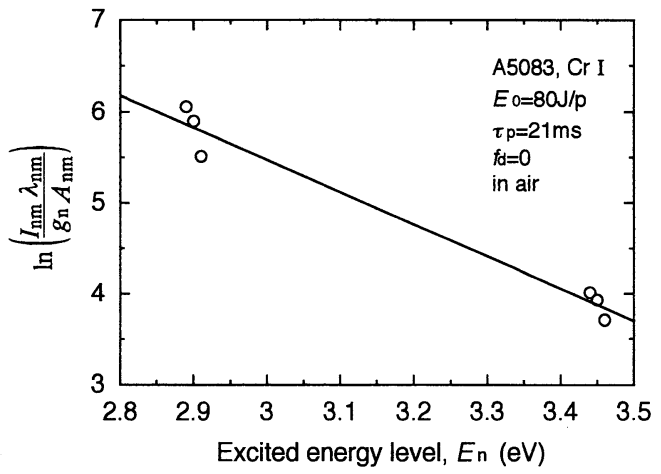

Fig. 10 Boltzmann plot of six CrI spectral lines of laser-induced plume from A5083.

$\pm 150 \mathrm{~K}$ と求められた。この温度はH.C.Peebles ${ }^{13)}$ らが求めたプラズマ温度 $(3400 \pm 300 \mathrm{~K})$ とほぼ一 致している。な㧍，これは連続の高パワー $\mathrm{CO}_{2}$ レーザー溶接などで求められた温度（約 6,000〜 13,000K）よりは低い。

プラズマの電子密度はSahaの式 (2) を用いて 推定した。

$$
S_{\mathrm{k}}=\frac{N_{\mathrm{i}} N_{\mathrm{e}}}{N_{\mathrm{a}}}=\frac{\left(2 \pi m_{\mathrm{e}} k T\right)^{3 / 2}}{h^{3}} \cdot \frac{2 Z_{\mathrm{i}}}{Z_{\mathrm{a}}} \exp \left(-\frac{V_{\mathrm{i}}}{k T}\right)
$$

ここで

$S_{\mathrm{k}}$ : Saha のイオン化定数

$N_{\mathrm{a}}, N_{\mathrm{i}}, N_{\mathrm{e}}$ : 原子, イオンおよび電子の密度

$m_{\mathrm{e}}$ : 電子の質量

$Z_{\mathrm{a}}, Z_{\mathrm{i}}$ : 原子とイオンの分配関数

$V_{\mathrm{i}}:$ イオン化エネルギー

プラズマ中の中性原子のスペクトル線強度 $I_{\mathrm{a}}$ と一価イオンのスペクトル線強度 $I_{\mathrm{i}}$ は, それぞれ 次式で表される。

$$
\begin{aligned}
& I_{\mathrm{a}}=N_{\mathrm{a}} \frac{g_{\mathrm{a}}}{Z_{\mathrm{a}}} A_{\mathrm{a}} h v_{\mathrm{a}} \exp \left(-\frac{E_{\mathrm{a}}}{k T}\right) \\
& I_{\mathrm{i}}=N_{\mathrm{i}} \frac{g_{\mathrm{i}}}{Z_{\mathrm{i}}} A_{\mathrm{i}} h v_{\mathrm{i}} \exp \left(-\frac{E_{\mathrm{i}}}{k T}\right)
\end{aligned}
$$

ここで,

$g_{\mathrm{a}}, g_{\mathrm{i}}$ : 励起準位の統計的重み

$E_{\mathrm{a}}, E_{\mathrm{i}}$ : 励起準位のエネルギー

$A_{\mathrm{a}}, A_{\mathrm{i}}$ : 遷移確率

$v_{\mathrm{a}}, v_{\mathrm{i}}$ : 遷移スペクトルの振動数
(3)と(4)式をそれぞれ分配関数について解いて, Sahaの式である(2)式に代入して $N_{\mathrm{e}}$ につて整理 すると，

$$
N_{\mathrm{e}}=\frac{I_{\mathrm{a}}}{I_{\mathrm{i}}} \frac{g_{\mathrm{i}} A_{\mathrm{i}} v_{\mathrm{i}}}{g_{\mathrm{a}} A_{\mathrm{a}} v_{\mathrm{a}}} \cdot \frac{2\left(2 \pi m_{\mathrm{e}} k T\right)^{3 / 2}}{h^{3}} \exp \left(\frac{E_{\mathrm{a}}-E_{\mathrm{i}}-V_{\mathrm{i}}}{k T}\right)
$$

となる。プラズマの温度掞よび同一元素の原子 線とイオン線の相対強度をそれぞれ測定すれば, 式 (5)の関係から熱平衡プラズマの電子密度が求 められる。

本研究において, A5083のレーザー誘起プルー ムの電子密度を求めるには, 前述のボルッマン プロットより求めたプルームの温度 $3280 \mathrm{~K}$ なら びに $\mathrm{Mg}$ 元素の中性原子線(333.668nm) と一価イ オン線(280.270nm)の相対強度を用いた。これよ り求められた電子密度は $N_{\mathrm{e}}=1.85 \times 10^{19} / \mathrm{m}^{3}$ で あった。以上の結果から, 本研究で用いた大気 中, $1.0 \times 10^{10} \mathrm{~W} / \mathrm{m}^{2}$ のレーザー照射条件では, A5083合金のパルスレーザー誘起プルームは, そ の温度が $\mathrm{Al}$ の沸点より約500K程度高い弱電離プ ラズマであることがわかった。

\section{4. 結 論}

レーザー溶接時の合金元素の蒸発挙動と誘 起プルームの物理量を高速撮影法および発光分 光分析法により検討した。得られた結果をまと めると以下のとおりである。

1)A5083の誘起プルームはレーザー照射中激し く変動しており, その変動周期は約450～ $500 \mu \mathrm{s}$ であった。これは, レーザービームと材料との工 ネルギーカップリングの変化によるキーホール の周期的変動に起因すると推察される。

2)CrI中性原子スペクトルの強度は試料表面付 近で最大となり, 一方, $\mathrm{AlO}$ 抢よび $\mathrm{MgO}$ の分子 スペクトルは, 高さ約 $5 \mathrm{~mm}$ の位置で最大となっ た。そして，いずれもその上方にいくに従って緩 やかに減少した。これは $\mathrm{Al}$ および $\mathrm{Mg}$ 蒸発原子 が, 試料表面上の空間を移動中に大気中の酸素 と化学反応を起こしていることを示す。

3)AlI と MgIの自己吸収現象の空間挙動は, 試 料表面の付近で強く生じ, 遠くなるほど弱く なっている。このことから, 溶接時には多量のAl 
と Mg原子が溶融池表面より蒸発し, 上方に行く ほどそれらの原子状態の濃度は少なくなること が推察される。

4)低パワー密度のレーザー照射条件において は, $\mathrm{MgO}$ の発光強度が支配的であり, 高パワー 密度では $\mathrm{AlO}$ が $\mathrm{MgO}$ よりはるかに高い強度を現 した。このような現象は1パルスのレーザー照射 期間中における発光強度の時間変化においても 同様に観察された。これらの原因は，Mgの沸点 および蒸発潜熱が $\mathrm{Al}$ より半分程度に低いことと 溶融池表面の温度状態から理解される。

5)大気中, $1.0 \times 10^{10} \mathrm{~W} / \mathrm{m}^{2}$ のレーザー照射条件 において，相対強度測定法により求められた レーザー誘起プルームの温度および電子密度は それぞれ $3280 \pm 150 \mathrm{~K}$ および $1.85 \times 10^{19} \mathrm{l} / \mathrm{m}^{3}$ で あった。したがって，Al-Mg合金のレーザー誘起 プルームは温度が $\mathrm{Al}$ の沸点より若干高い弱電離 プラズマであると結論される。

\section{謝 辞}

この研究の一部は, (社)軽金属溶接構造協会の プロジェクト研究の援助を受けたことを記し， ここに謝意を表します。

\section{参 考 文 献}

1) 松縄朗, 金 鍾道, 片山聖二, 竹本 正: レー ザー研究, 24 (1996) 679.
2) 日本金属学会編：金属データブック(3版) (丸 善, 東京, 1993).

3) C. E. Moore: Atomic Energy Level (Circular of the National Bureau of Standard 467, Vol. I, Washington, 1949).

4) 金 鍾道, 片山聖二, 竹本 正, 松縄 朗：溶接 学会全国大会講演概要第 57 集 (1995, 秋) p.440.

5) R. W. B. Pearse and A. G. Gaydon: The Identification of Molecular Spectra (Chapman and Hall LTD, London, 1976).

6) H. R. Griem: Plasma Spectroscopy (McGraw-Hill, New York, 1964) Chap. 6.

7) 松村年朗, 作田忠裕：電気学会論文誌, 110 (1990) 765

8) J. Jarosz, J. M. Mermet and J. P. Robin : Spectrochimica Acta, 33B (1978) 55.

9) N. Furuta and G. Horlick : Spectrochimica Acta, 37 (1982) 53.

10) W. Sokolowski, G. Herziger, E. Beyer : Proc. SPIE, 1020 (1988) p.96.

11) C. H. Corliss, W. R. Bozman: Experimental Transition Probabilities for Spectral Lines of Seventy Element (NBS Monograph 53, 1962).

12) S. Bashkin, J. O. Stoner: Atomic Energy Levels and Grotrian Diagrams (North-Holland, Vol. I, Oxford, 1975).

13) H. C. Peebles and R. L. Williamson: Proc. of LAMP'87 (High Temperature Soc. of Japan, Osaka, 1987) p. 19.

\section{レーザーワード}

時間分解レーザープラズマ軟 X 線吸収分光

(Time-resolve。 Laser Plasma Soft X-ray Absorption Spectroscopy : TR-LAPXS)

まず，ナノ秒やピコ秒のパルスレーザーを真空中で金属ターゲットに照射して所謂レーザープ ラズマを生成する。そこから，それぞれナノ秒やピコ秒のパル ス軟X線が放出される。これをプ ローブビームとして用い，透過スペクトルを検出することによってパルス的な半導体プロセスや 物質の高速相変化の時間変化を観測することができる。この時間分解軟 X線吸収分光測定はシン クロトロン放射光 (SR) を用いても可能であるが，本手法はポンプビームとプローブビームとの 時間差を自由に調整して，簡単に時間分解測定を実験室規模で行える点が特徵である。また，原 子, イオン, クラスターと数十ナノメートルのサイズの超微粒子まで気体, 液体, 固体にかかわ らず測定できるため, XANESやEXAFSの測定による時間分解構(電子構造および幾何学的構造) 测定法としても期待される。 (村上 浩一) 